\title{
The Chimpanzee and Me, by Ben Garrod
}

\section{Zephyr (Head of Zeus), London, 2019, pp. 200, Paperback ISBN: 9781788547611. UK 10.99 pounds sterling}

\author{
William C. McGrew ${ }^{1} \mathbb{D}$
}

Received: 25 June 2020 / Accepted: 25 June 2020 / Published online: 23 July 2020

(c) Japan Monkey Centre and Springer Japan KK, part of Springer Nature 2020

Primatologists are sometimes asked by friends or family to recommend a book that will introduce them to nonhuman primates. As a primatologist who studies chimpanzees, I am often asked to suggest a book that teaches something about this particular species, usually starting from zero. It is easy to recommend a proven classic, such as de Waal's Chimpanzee Politics: Power and Sex among Apes (1973) or Goodall's In the Shadow of Man (1971), which were worldwide bestsellers, but these books are now decades old. So what should one recommend as an up-to-date, readable synthesis that especially emphasizes the perilous state of our endangered cousins? With the publication of Ben Garrod's new book The Chimpanzee and Me this problem is now solved.

Garrod, who is Professor of Evolutionary Biology and Science Engagement at Anglia Ruskin University, Cambridge, is both a field and laboratory primatologist. His fieldwork includes the study of chimpanzees in Uganda, and laboratory work with green monkeys in Barbados. (The title of his $\mathrm{PhD}$ thesis was Primates of the Caribbean, reflecting a sense of humor that is not unlike that of Jack Sparrow.) Garrod also has a career as a presenter of BBC television documentaries on zoological topics, the latest of which, Baby Chimp Rescue, is tied to this book. This documentary is in three parts and shows the ups and downs of the committed work of Jimmy and Jenny Desmond, who run a sanctuary in Liberia for confiscated chimpanzees, mostly orphaned youngsters.

The book spans the threats to wild chimpanzees that necessitate such a refuge, such as habitat destruction, the pet trade, hunting for bush meat, and disease. These are serious topics, and Garrod meets them head on, with his

William C. McGrew

wcm2@st-andrews.ac.uk

1 School of Psychology and Neuroscience, University of St Andrews, South Street, St Andrews KY16 9JP, Fife, UK writing lightened by irony and occasional sarcasm, especially in the 146 clever, self-deprecating footnotes. (I cannot recall the last time I saw footnotes-an endangered species in themselves these days-used so skillfully for light relief.) The other engaging feature of the book is its 58 high-quality color photographs, mostly appealing portraits of named young chimpanzees that live in the Desmonds' sanctuary. However, the book does have some drawbacks, at least for someone seeking to follow up its introduction to the species, as there are no citations, bibliography, index, or list of books for further reading, just three website links. Still, the book is good value for money, and the proceeds go to chimpanzee projects in Africa.

The author's opening chapter sets the scene with a case study, the life story of a young female chimpanzee, and Garrod's first encounter with her at Liberia Chimpanzee Rescue and Protection. (He returns to this chimpanzee in the final chapter, by which time the reader can appreciate all that he and she have since experienced.)

Crucially, the next chapter distills nicely, from ground zero, the answer to the basic question: what is a chimpanzee? It is clear and concise on everything from the scientific discovery of the chimpanzee to current knowledge of its taxonomy, morphology, diet, ecology, etc. This account of the chimpanzee is further fleshed out in a later chapter in a $Q$ and $A$ interview with Jane Goodall, which ranges over mostly behavioral topics. This latter chapter contains little information that is new to primatologists, but allows beginners to relate the species to its most famous proponent. [It mentions an important point that is sometimes forgotten today about Goodall's scientific work: she was the first scientist to publish comparative data on cultural differences between chimpanzees (Goodall 1973), way back in the early 1970s.]

Another chapter describes the hands-on rehabilitation of the orphans at the sanctuary via human-to-ape "schooling," 
as although they were wild born, most of the orphans were taken into captivity long before they had acquired even basic survival skills from their mothers. The lessons include orchestrated positive experiences, such as learning to crack nuts with stones or to fish out food from an artificial termite mound, and negative ones, such as learning to fear (model) snakes. This pedagogy replicates methods used by Stella Brewer (1978) in her chimpanzee rehabilitation project in the Niokolo-Koba National Park, Senegal in the 1970s.

Some chapters on threats to chimpanzees describe empirical and specific research, such as Garrod's analysis of the primate pet trade in the UK. This trade does not include chimpanzees (the keeping of which is banned in the UK) but does include many more New World monkeys and lemurs than most people probably realize. Another chapter gives a first-hand description of the challenges of confiscating an illegally kept pet chimpanzee from a village, even when the police are present, where the owner and his friends are resistant. The gripping rescue operation, which is told stepby-step, is ultimately successful.

The chapter on the bush meat trade with its accounts of painful and sometimes fatal snaring is harrowing, and really hits home given the current pandemic of Covid-19. (I write this review during my ninth week of self-isolation at home.) Garrod uncannily describes, almost prophetically, how a zoonotic disease can be globally disastrous: "From the perspective of someone who does not want to be in the middle of the next global pandemic... Imagine if it mutated with a flu virus and produced a new disease... Imagine something so devastating starting from the blood of a bat on a small market stall somewhere...' (p 124). This makes for chilling reading.

Liberian chimpanzees have also had their share of other types of suffering, given their confinement at Vilab II and use in biomedical research done by the New York Blood Center. Again, Garrod provides a case study based on specific data: a female chimpanzee who was anaesthetized 345 times, had 49 liver biopsies, and all her teeth removed. Yet she survived, and was subsequently cared for by the Desmonds. Garrod is condemnatory, but surprisingly reticent about naming the people who carried out this maltreatment.

The longest chapter is the summing-up of current conservation and welfare efforts (which are difficult to separate these days). It provides good examples of successes (Goodall's phrase, "reasons for hope," is applicable here), such as the sale of greeting cards illustrated with snare wire recycled by local people, which sends a pointed conservation message. But the chapter is more than an exercise in cheerleading as it contains useful information, such as the distinction between flagship and umbrella species in preservation efforts. (Chimpanzees can qualify as both.)

In summary, Garrod has given us a carefully crafted account of the current status of our nearest living nonhuman relations that is accessible to all, especially young adults. As also evidenced by his television work, Garrod is a gifted academic storyteller with many important points to make. Read and enjoy!

\section{References}

Brewer S (1978) The chimps of Mt. Asserik. Knopf, New York de Waal F (1973) Chimpanzee politics: power and sex among apes. Johns Hopkins University Press, Baltimore, MD

Goodall J (1971) In the shadow of man. Collins, London

Goodall J (1973) Cultural elements in a chimpanzee community. In: Menzel EW (ed) Precultural primate behavior. Karger, Basel, pp 144-184

Publisher's Note Springer Nature remains neutral with regard to jurisdictional claims in published maps and institutional affiliations. 